\title{
Litteratur og afføring
}

\section{Med særligt henblik på Peter Seebergs $0 m$ fjorten dage}

Der er visse ting, man ikke taler om. Afføring f.eks. Det er noget, man går for sig selv og gør. Hvis der er problemer med det, kan man tale med sine nærmeste, eventuelt med sin læge. Ellers holder man det for sig selv og får det overstået.

Sådan har det som bekendt ikke altid været. Det er der i øvrigt intet der har, altså heller ikke afføring. Uffe Østergaard skrev i 1985 en artikel, der netop argumenterede for det historiske i fænomenet. ${ }^{1}$ Uffe Østergaards ærinde er først og fremmest at argumentere for vigtigheden af sædeskildringens bidrag til den almene historie og at fremsætte en kritik af forestillingen om 'civilisationshistorien' som en konstant forbedring. Der klinger således en umiskendelig fascination med i hans beskrivelse af livet i ærkebispens palads i Orvieto i Mellemitalien: »Rummets indretning indebærer, at herren og slotsfruen har spist, drukket, ræbet, forrettet nødtørft og haft samleje om ikke sammen med hoffet, så direkte for øjnene af gæster og tjenerskab. $\mathrm{Og}$ at disse ligeledes har forrettet alle de samme funktioner i dette samme rum. Begrebet privathed har simpelthen ikke eksisteret for middelalderens mennesker, hverken fysisk eller åndeligt. ${ }^{2}$ Senere hierarkiseres denne åbenhed, således at det f.eks. under solkongen var et privilegium at være tæt på kongen og hans legemlige funktioner. Det var således et betroet job at kontrollere monarkens afføring i natpotten, og det kunne siden føre til jobbet som skatmester. »Enhver freudianer kender sammenligningen mellem fækalier og penge«, bemærker Østergaard tørt. En bemærkning vi skal have in mente i det følgende.

Da Uffe Østergaard skrev sin artikel i 1985 havde han givetvis læst Norbert Elias' banebrydende værk Über den Prozess der Zivilisation, oprinde-

1. Uffe Østergaard: „Kærlighed, afføring og fremskridt - mentalitets- og civilisationshistoriske problemstillinger«, in: Acta Jutlandica nr. 60, Århus 1985.

2. Loc. cit. p. 252. 
ligt skrevet i 1936, men udvidet og genudgivet i 1969. Måske havde han også nået at blade i Philippe Ariès' Histoire de la vie privée, hvis første bind udkom samme år som Østergaards artikel, 1985. Især Elias’ måde at gribe kulturhistorien an på, synes at have inspireret Østergaard, selv om en del af hans teoretiske polemik er rettet mod det civilisationsbegreb, som Elias stadig bekender sig til. I det i vor sammenhæng mest interessante kapitel, "Wandlungen in der Einstellung zu den natürlichen Bedürfnissen« fremhæver Elias især Erasmus af Rotterdam som en betydningsfuld overgangsfigur. I sit skrift De civilitate morum puerilium fra 1530 gør han sig ganske vist til talsmand for en vis disciplinering af de naturlige behov og - også af hygiejniske grunde - for en adskillelse af disse behovs forrettelse fra øvrige aktiviteter. På den anden side er han endnu del af en kultur, hvor man uden nogen skamfølelse kunne tale om dette som den helt naturlige og selvfølgelig del af menneskelivet, det nu engang er. ${ }^{3}$ Det er denne åbenhed, Elias registrerer går tabt i de følgende århundreder, og som hans egen forskning i en vis forstand er et bidrag til at genetablere. Hans værk gør forsøg med beskrivelsen af det ubeskrivelige, med benævnelsen af det unævnelige.

Philippe Ariès og hans medarbejdere i The History of Private Life giver også Erasmus' skrift en central plads i afføringens kulturhistorie, men viser også hvordan den fremvoksende bykultur allerede fra 1400-tallet bekymrede sig om det menneskelige affald. Udviklingen af hygiejnen, privatlivsopfattelsen og en mere restriktiv kropsmoral går hånd i hånd, det ene betinger det andet og det er tit svært at se, hvad der kommer først. Hvor forrettelsen af nødtørft i en argrarkultur helt op i 1800-tallet hovedsageligt foregik i naturen, og i den tidlige bykultur kun svagt afskærmet i direkte forbindelse med det offentlige liv, bliver indretningen af særlige rum til den slags aktiviteter mere og mere almindelige fra 1400-tallet og fremefter. "Selv almindelige huse var udstyret med latriner, i højere grad end man skulle tro«, skriver Ariès, ${ }^{4}$ og giver i forlængelse heraf en levende beskrivelse af to familier i Rouen, der i 1433 fandt ud af at dele 'fælles lokum på trappen', øjensynlig både til gavn for hygiejnen og nabokontakten.

Samtidigt med at sædelighed og moral mere og mere tilsiger, at pleje af kroppens behov skal ske i gedulgthed, bliver det også en del af en den autoritære overvågning, at man kan overvåge 'indsattes' - forbrydere, syge eller sindsyges - nødtørft. Michel Foucault tematiserer mig bekendt ikke direkte toiletfunktioner i sine beskrivelser af autoritets- og magtformernes udvikling. Men i eksplicit forlængelse af bl.a. Philippe Ariès peger han på det ambivalente i den rumfilosofi, som karakteriserer 1700-tallet - den peri-

3. Jf. Norbert Elias: Über den Prozess der Zivilisation, Frankfurt a.M. 1980, p.174 ff.

4. A History of Private Life, II, Cambridge, Mass. 1988, p. 463 
ode hvor det moderne dominanssystem udvikles. Her sker der en differentiering og sektionering af beboelsesrummet og huset og en opdeling af de funktioner (spisen, socialt samvær, elskov, forrettelse af nødtørft og søvn), der hidtil er foregået pêle-mêle. Udviklingen af intimitet i seksuelle og andre fysiske aktiviteter er både dikteret af moralske og hygiejniske grunde. Samtidigt ser vi i det 18. århundrede opkomsten af rigide overvågningssystemer både inden for lægevidenskab, militærvæsen og straffesystemer, der både bygger på et behov for total kontrol med samfundsmedlemmerne og på en tro på offentlighed og åbenheds helbredende kraft. I det Benthamske fængsel, der er prototypen på Foucaults overvågningssystem, kunne vogteren se alt, hvad den indsatte lavede i døgnets 24 timer, herunder selvfølgelig også hans afføring. Opkomsten af den radikale fortrængning af kroppen fra det offentlige rum afføder den radikale overvågning som straf. Hele dilemmaet i den franske revolutions tro på blikkets og lysets kraft ligger i denne modsætning. ${ }^{5}$

Interessant i Foucaults uhyre sammentrængte og komplekse argumentation er også hans pointe, at udvikling af den offentlige opinion og de dermed forbundne moderne medier også er et resultat af troen på den totale åbenhed. „De så ikke, at disse medier nødvendigvis ville komme ind under økonomisk-sociale interesser«, bemærker Foucault, hvor 'de' sigter til de franske revolutionære. ${ }^{6}$ Denne dobbelthed både i udviklingen af forholdet til det intime og i forholdet til det skrevne ord er en pointe, vi også godt kan tage med os, når vi nærmer os temaet 'afføring og litteratur'.

For at også litteraturen gennem tiderne på forskellig måde har behandlet afføringen, kan jo ikke undre. Og det er egentlig forbavsende, at ingen mig bekendt hidtil har helliget sig dette oplagte forskningsemne. "Lorten i litteraturen«: alene den flotte alliteration i titlen gør opgaven indbydende. Men ingen har hidtil vovet at tage den op, altså opgaven, hvad det så kan skyldes.

Det synes, som om den privatisering af afføringen, som kulturhistorien beskriver fra omkring $1500 \mathrm{og}$ fremefter, ikke med det samme og i samme omfang sætter sig igennem som fortrængning i litteraturen. Den fortrængning af 'det menneskeligt, alt for menneskelige', som Elias og elever konstaterede og som de i en vis forstand ville modarbejde med deres forskning, har måske aldrig været helt så markant i litteraturen, hvis rolle siden det epistemiske brud med det klassisk-middelalderlige verdensbillede $\mathrm{i}$ alt fald

5. Hvad angår Foucaults bidrag til denne filosofi se f.eks.: »The Eye of Power. A conversation with Jean-Pierre Barou and Michelle Perrot« in: Michel Foucault: Power/Knowledge. Selected Interviews and Other Writings 1972-1977, ed. Colin Gordon, New York 1980, p.146 ff.

6. Op. cit. p.162. 
delvist har været at tage sig af menneskelivets marginale, 'abjektale' sider. Men som sagt: vi mangler grundforskning.

I dansk litteratur har vi imidlertid et berømt eksempel på tematisering af forholdet mellem afføring og litteratur så sent som 1792, hvor Jens Baggesen i Labyrinten gav en skildring af parallellen mellem legemets og sjælens »laxeren«: »Det er saa væsentlig nødvendigt for begge, og taber saa ganske sin dobbelte Anvendelse i Historien Mørke, at jeg holder den opgave: om Sielen først har lært af Legemet, eller Legemet af Sielen? for ligesaa uopløselig, som den, om Drikken har været før Tørst eller Tørst før Drikken? Man indseer lettelig, at jeg ikke tager dette Middel blot i sin kunstige men og i sin naturlige Forstand, og indskrænker det ikke til noget vist Species; hvorfor man og med eet almindeligt Udtryk kunde kalde det: Afføring. ${ }^{7}$ Som forfatter, og især som prosaforfatter, hvis »daglige Stoelgang "kræver mindst én linie, har Baggesen nu pålagt sig "strængeligen [at] adlyde dette store Naturens Bud: at uddunste. $\|^{8} \mathrm{Og}$ har til den ende (!) besluttet sig for at føre dagbog som en daglig nødvendig renselse. Gør han ikke det, slutter han sine betragtninger, vil det komme til at gå ham som »vor for Resten berømmelige Tyge Brahe«: »Selv den ellers meget priisværdige Undseelse for Selskabet kan ikke undskylde en saadan Efterladenhed; thi Cicero har eengang for alle rigtigen bemærket, at - Naturalia non sunt turpia... «"

Stedet er typisk for Baggesen i Labyrinten: han bekender sig til det menneskelige, alt for menneskelige og til at naturen ikke er snerpet, samtidigt med at han som i eksemplet her forudsætter en historisk og litterær viden af læseren (om at Tyge Brahe døde af en sprængt blære, fordi han af generthed kviede sig ved at forlade et selskab for at gå på WC) og belægger sin visdom med sentenser af Cicero og andre klassikere. Hans uhæmmede naturalisme kombineres med den højeste intellektualisme; som også i et af mine yndlingssteder i Labyrinten, hvor han afsværger hele metaforteorien og deklamerer, at en sommerfugl er en sommerfugl og ikke 'betyder' noget, og at han i Mainz blev en sommerfugl: "jeg havde groveligen forløiet mine Læsere, hvis jeg her havde bragt mindste Fiær af Minervas Fugl i Erindring. ${ }^{10}$ Han tilbageviser al symbolicitet og lærdom ved at appelere til vores klassiske dannelse og vores viden om, at Minervas fugl, uglen, er visdommens symbol. Contradictio in adjecto. Baggesen taler gerne om to ting på samme tid, og underminerer ofte sine udsagn med en anden mening. Således også, når han taler om afføringen i skriveprocessen: han siger bestemt ikke dermed, at han anser sin digtervirksomhed som det rene lort, men at den

7. Jens Baggesen: Labyrinten, Gyldendals bibliotek bd. 4, Kbh. 1971, p. 61.

8. Ibid.

9. Op. cit. p. 63.

10. Op. cit. p. 243. 
indeholder en »rest« (læg mærke til formuleringen omkring Tyge Brahe), et fordøjelsesprodukt, som det er nødvendigt at medtænke og at medforstå, hvis man vil begribe hans teksters mening. Det er denne 'omsætning', denne tvetydighed som er kernen i Baggesens digterunivers.

Hvor meget Baggesens sammenligning mellem digtning og afføring forargede hans samtid, ved jeg ikke, men jeg forstår hans frimodighed som rest af en gammel ikke-fortrængt kultur omkring disse menneskelige aktiviteter. Med romantikken sker fortrængningen totalt. Jeg har ikke set efter med dette for øje, men jeg kan ganske simpelt ikke forestille mig PalludanMüllers Adam Homo på lokum. I det hele taget vrimler dansk litteratur i 1800-tallet ikke med lokumsskildringer, selv om de såmænd nok skal vise sig at være der, hvis man går til margenen i åndslivet. Den alkoholiserede urmager Fritz Jürgensen tegnede i alt fald i 1840 'erne flere billeder af 'det lille hus' med antydning af, hvad der foregik derinde. Og ude i den store verdens litteratur var der skam i f.eks. Eugene Sues Paris' mysterier adskillige indikationer af, hvad der befandt sig i storbyens kloakker og af, hvordan det var kommet derned. Også i 1800-tallets åndsliv levede afføringen sit ubevidste liv i psykens nedre regioner.

Men ellers var det jo først med det 20. århundredes friske vind, at der også blev åbnet op til retiradernes verden. Med Leopold Blooms berømte toiletbesøg i 4. kapitel af Ulysses fra 1922 vender afføringen igen tilbage til verdenslitteraturen på dens med rette tilkomne plads. Det er her interessant at bemærke, at Joyce har samme fokus på sagen som Jens Baggesen havde 130 år tidligere: ingen af dem interesserer sig for resultatet, afføringen, men kun for processen, peristaltikken. Hos Bloom er hans gode, velfungerende afføring en del af hans flydende væsen og forbinder ham med vandets element, sådan som det tages op og udbygges i begyndelsen af »Ithaca«-kapitlet nogle hundrede sider længere fremme. Modsat erfarer vi jo, at hans i alle henseender modpol, Stephen Dedalus, har problemer med vand. Men i symbolet mødes de alligevel omkring dette element: da Stephen går ved havet og får en inspiration, river han et stykke papir af et manuskript og kradser et digt ned. Da Bloom er færdig med sit ærinde her i 4. kapitel, river han et stykke papir af en præmienovelle og tørrer sig. Forskelligt og dog parallelt: Stephen river papir af til digterisk virksomhed, Bloom til brug på toilettet. Afføring og digtning er endnu engang forbundne i værket. Man tænker, selv om man ved det er umuligt: har James Joyce kendt Jens Baggesen?

Desværre levner pladsen her kun mulighed for korte nedslag i dette righoldige emne; men for at nærme os det, der er vort egentlige ærinde, Peter Seeberg, skal opmærksomheden henledes på en af de besynderligste episoder i dansk litteratur: kapitel 2 i Johannes V. Jensens roman fra 1935 Dr. Renaults Fristelser. Som man ved, er der tale om en Faust-historie, hvor 
denne dr. Renault efter døden får muligheden for at vende tilbage til jorden, mod at han forskriver sin sjæl til Mefisto, der hos Jensen hedder Asbest. Det kommer der en forviklet, pikant og sine steder yderst absurd forestilling ud af. Hvad der i vor sammenhæng er interessant er, at den episode, der falder Dr. Renault ind, da han første gang ligger for døden, og som er det, der først og fremmest udløser hans begær efter at vende tilbage til jorden - handler om en voldtægt på et jernbanetoilet! Episoden udspillede sig på en lille belgisk station, mens han som ung mand var på rejse til Paris. Lokomotivet skal checkes, og i mellemtiden får den unge rejsende lidt at drikke i restauranten og går efterfølgende over for at bruge toilettet. Her møder han sin skæbne i form af en rengøringskone, og så har vi en konstellation, der minder om Seebergs i »Forsøg med vrede« fra Om fjorten dage fra 1981: kvindelig toiletrenser contra mandlig bruger. En arketypisk situation, synes det.

Der er også en grundlæggende lighed i de to situationer: rengøringskonen er den nederste, den mandlige bruger er den overlegne, han har magten. Det ligger i luften uden at det nogen steder formuleres så vulgært: han skider på hende. Begge steder er der også en tydelig social dimension i konstellationen, hos Jensen bliver det eksplicit betonet, at konen er repræsentant for folket: "Typen havde noget decideret folkeligt, Udtrykket ejendommelig permanent forlystet, saadan som hun saa ud idet hun vendte sig om, lidt med Næsen til Vejrs, moquerende, en væbnet Sindstilstand, men med Humor i, som kan observeres hos arbejdende Kvinder, af en Aarsag der altid er den samme, Mandfolk at holde fra Livet «. ${ }^{11}$ Kampen om/på lokummet er klassekamp og kønskamp i ét, uden det ene ikke det andet, som rødstrømpebevægelsens slogan lød i 70’erne.

Men afviklingen af toiletepisoden er vidt forskellig hos Jensen og hos Seeberg, og denne forskel vil givetvis være signifikant, når afføringens danske litteraturhistorie engang skal skrives. Hos Jensen sker der nemlig det, at den rejsende fuldkommen glemmer sit formål med at indfinde sig på toilettet og forvandler sit oprindelige behov til seksuelt begær. Der er en slags pervers sublimering i dette: $\mathrm{i}$ stedet for at skide, voldtager han. Og det grotesk misogyne i Jensens tekst er, at kvinden nyder det. Scenen er en svælgen i maskulin brunst: ».. der stod en Livslugt om hende af Blod og Mælk, som fra unge Kvier, blandet sammen og forstærket af den bidende, stikkende Lugt i Rummet af Sæbe, af Klorkalk og af Ammoniak... «, etc. ${ }^{12} \mathrm{Og}$ hun kan ikke få nok: "... hun strittede imod og blev brudt ned Gang på Gang, det kunde ikke gentages for tit, lod det til, hun gik bagover med Hovedet og lukkede Øjnene, kunde ikke taale at se forvorpen Adfærd, men nød godt deraf

11. Johannes V. Jensen: Dr. Renaults Fristelser, Kbh. 1935, p.14.

12. Op. cit., p.15. 
med Hovedet i Busken« (ibid.). Til sidst »flytter de sammen«, som der eufemistisk står: de går ind på et af toiletterne »og her sikrede de sig Enrum ved at hægte Krogen paa indvendigt«. Hic Rhodus, hic salta. Men så lyder pludselig togets afgangsfløjte og den unge dr. Renault må afbryde stævnemødet på lokummet og ile til sin kupé. Det svier til ham senere, der var noget, han i mere end én forstand fik afbrudt her, og derfor må han senere vende tilbage til jorden. I det følgende er det uklart, om Dr. Renaults brøde var, at han i sin ungdom forbandt nødtørft og seksualitet, eller om det i virkeligheden var den intense forbindelse mellem disse to menneskelige aktiviteter, der var det højdepunkt i hans liv, han aldrig senere nåede. Det er det tvetydige i situationen, der den dag i dag gør denne lokumsepisode så fascinerende. Da Dr. Renaults Fristelser udkom, må den have været en provokation.

Jeg ved ikke, om Peter Seeberg har kendt Dr. Renaults Fristelser, men man kan ikke udelukke det. Han har som den kulturhistoriker, han også var, ganske givet kendt Norbert Elias og hans forskning i civilisationsprocessen og sikkert sympatiseret med den. Som arkæolog har han om ikke ligefrem haft fingrene begravet i afføring (det er jo noget af det første der forsvinder), så dog erfaret, at affald er en fortrinlig vej til forståelse af menneskelig adfærd og et nødvendigt redskab i historieforskningen. En hel kultur i dansk oldtid er kaldt op efter en mødding: Ertebølle, oven i købet beliggende ikke så langt fra Seebergs hjemby, Viborg. Seeberg må formodes at have haft forstand på affaldsprodukter.

Ikke så sært da, at han gør lokummet til et af nøglestederne i det billede af en sønderjysk stationsby, som han opridser i 10 små historier, novellesamlingen Om fjorten dage fra 1981. Han ved godt, at i forhold til det, Kristeva kalder »det abjektale« og som hun selvfølgelig forstår bredere end lige afføring, afslører mennesket sine dybe identiteter. I Seebergs univers, der handler om begivenheder i 1927, men afspejler en bevidsthed fra slutningen af det 20. århundrede, indtager afføring og lokummer deres i mere end én forstand naturlige plads, og umiddelbart kunne det synes urimeligt at gøre noget specielt ud af det. Det er som sagt ikke noget man taler om, men går for sig selv og gør. Men Seeberg taler om det, og læser man disse 10 historier fra den sønderjyske stationsby opmærksomt igennem viser det sig da også, at helt så enkelt er det ikke. Lokummet og de menneskelige aktiviteter, det er forbundet med, udgør en central kampplads for stedets konflikter. Afføringen er noget, der skal overvindes - ikke fortrænges, men netop overvindes; men ikke som Seebergs store idol, Nietzsche formulerede det: mennesket er noget, der skal overvindes. ${ }^{13} \mathrm{I}$ Om fjorten dage sker overvindelsen,

13. Jf. Zarathustras tale til folket: „Ich lehre euch den Übermenschen. Der Mensch ist Etwas, das überwunden werden soll« in: Also sprach Zarathustra, Leipzig 1919, p.13. 
fordi der i det sønderjyske samfund opstår en godhed, der renser op i angsten for smudset og kan åbne op for en forsoning med det kreaturlige. Den øjensynlige ligefremhed, hvormed Seeberg i Om fjorten dage skildrer afføring, udsender alligevel et dobbeltsignal: på den ene side siger den, at afføring er en menneskelig aktivitet som alle andre og må behandles som sådan. $\mathrm{Og}$ på den anden side udnytter den den provokation, der trods alt er i denne åbenhed, til at pege på denne aktivitet som en del af den dominans, angst $\mathrm{og}$ fremmedhed, som råder i dette samfund og som kalder på en frelse. Det er dette dobbeltsignal, det følgende kort skal skitsere.

Men før vi nærmer os dette sted et par bemærkninger om den måde, temaet forberedes på i de to noveller, der i samlingen Om fjorten dage står umiddelbart før de ti historier om den sønderjyske stationsby. I novellen »Drømmen om folket (1875-76)« slår det således én, at den unge lærer, vi her møder under hans slidsomme jagt på folk, der kan synge de gamle folkeviser, både har problemer med sin afføring og med sin indsamling. Skønt han går uden for byen og finder sig et passende sted i læ af et hegn, vil maven ikke rigtig reagere ${ }^{14}$ Der kommer først gang i den, da han får hul på sin indsamling, igen synes afføring og tekst at følges ad. Hans succes med indsamlingen er dog kun betinget, idet han ganske vist får 30 viser af den blinde Martine Andersdatter, men hans besøg udløser samtidigt sønnens vrede mod moderen, og han slår hende ihjel med en økse, før vor optegner når at komme tilbage og få resten af Martines sangskat. At det skal kunne lykkes ham at få den gennem sønnen, som nu sidder i Viborg arrest, tror vi ikke rigtigt på: moderniteten er slået igennem på landet, og den drøm om folket, som drev den unge lærer, er bristet. Nu kommer der også snart en jernbanestation, erfarer han, og selv om vi igen får at vide, at »(n)æste morgen gik han atter ud af byen og fandt et hegn og græsset var stadig tørt, og det gik helt godt» (p. 65), så ved vi det allerede: der vil ikke alene komme en jernbanestation, men også et jernbanetoilet. Den frie nødtørft i naturen, som det alligevel trods startbesvær lykkedes den unge visesamler at få reguleret, vil være en saga blot.

Også i den næste novelle, »Erinde om formiddagen. 1893«, er et lokum diskret, men tydeligt placeret. Det tilhører den garver, der skal præparere skindet fra oberstindens døde kat, som den unge oppasser Christian kommer med. Den bliver i første omgang hugget og smidt i floden af nogle uvorne drenge, men Christian vender tilbage til garveren og overtaler ham til at finde en anden kat og præparere dennes skind. Forhandlingerne med garveren finder sted, mens denne befinder sig bag "et nødtørftsskjul i et

14. Peter Seeberg: Om fjorten dage, Kbh. 1981 (Gyldendals tranebøger), p. 55. Hvor intet andet er nævnt, er sidehenvisningerne i det følgende til denne udgave. 
hjørne af gården« (p. 73), hvilket medvirker til at understrege stedets forbindelse med hadefuldhed, smuds og kadavre. Den anden sfære udgøres af det ledvogterhus, Christian søger ly og hjælp i, og hvor datteren er lige så gravid, som han kone hjemme i en fjern landsby. Historien foregår i Metz, på handlingstidspunktet under tysk okkupation, og da ledvogterdatteren skal have kortet frem for at finde Christians fjerne hjemby kunne man få den tanke, at denne befinder sig i et andet af Tyskland besat område: Sønderjylland. Muligheden for hurtig kontakt mellem disse to områder er et tog, som det, der regelmæssigt suser forbi ledvogterhuset. Toget bliver derfor symbol på det modsatte af smudsens og lokummets verden: familien og det barn, som netop bliver født i Sønderjylland, men som Christian ikke kan nyde tanken om, fordi han er bundet til bedraget omkring katten. Nødtørft er bundet til magt og underkastelse (selv om garveren egentlig er flink nok), toget til frihed og forløsning. Det er dog et håb, som den følgende suite af historier om en sønderjysk landsby i november 1927, ikke rigtigt indløser.

Som sagt består dette landsbyportræt af ti små historier, alle med tidspunktet angivet i parentes, men suiten afsluttes med en tekst nr. elleve, »Biografi af en snegl«, hvor den nøjagtige tidsangivelse mangler. Hvor rækkefølgen af daterede historier begynder med beskrivelsen af en kamp om jernbanestationens lokum, en konflikt hvor magthaverens ret til at svine og stinke, som han har lyst til, støder på den kvindelige underordnedes modstand, og hvor vreden krystalliseres og et langt historisk perspektiv antydes, integreres det slimede og i bogstavelig forstand dyriske i den afsluttende historie på en naturlig måde i stationsbygningen. Den beskriver på halvanden side en snegls vandring fra maj til november ned gennem landsbyen, hen over hovedgaden og jernbanen, indtil den når stationsbygningen, hvor den trænger ind og sætter sig fast. Her går tiden i stå, »fremtiden syntes overflødig«, som der står (p. 191), og det biologisk-kreaturlige synes at have fået ret til at være i stationsbygningen. Kampen om lokummet har fundet sit forsonende perspektiv i en snegls finden-hjem til vintermørket. Rejsen står ikke i modsætning til smudset, men er en proces i dette.

Men før vi når så langt, har vi været vidner til en kamp om køn og magt, hvor smuds og afføring $\mathrm{i}$ alt fald i begyndelsen spiller en afgørende rolle. I Seebergs sønderjydske univers er lort og pis den magtfulde mands domæne, og hvis kvinderne har det svært med det, er det fordi de i det hele taget har det svært med mænd. Det gælder rengøringskonen Bothilde i den første af historierne »Forsøg med vrede«, der ikke i almindelighed er bange for lort, men ikke kan klare, at trafikkontrollør Jensen skal benytte personaletoilettet, lige før hun skal gøre det rent. Der går hendes grænse, og selv om hun ikke har mod til at sprænge lokummet inklusiv Jensen i luften, mener hun selv, at hun med sin opførsel har skræmt ham så meget, at hun har udsigt til 
at vinde magtkampen på længere sigt. Hendes egentlige problem er dog nok hendes indremissionske mand derhjemme, Alfred, der også seksuelt synes at være så fredelig, at han ikke kan give hende styrke til at udholde Jensens hørmeri. Alligevel er der i Bothildes oprør en begyndelse til den suveræne kvindemagt, der i husbestyrerinden Huldas skikkelse afslutter de daterede noveller. Men her har den stoute trafikkontrollør Jensen da også forvandlet sig til den stangberusede Hermansen, der oplever, at man ikke kan købe alt for penge, ikke engang for $2000 \mathrm{kr}$. retten til at holde servitricen i hånden hele natten (jfr. p. 184). Hvor Jensen havde kontrol over afføringen, har Hermansens penge ingen magt. Vi husker Uffe Østergårds påmindelse om, hvordan Freud har beskrevet den nære forbindelse mellem fækalier og penge.

Hvor trafikkontrollør Jensen dominerer kvinden ved at bruge toilettet lige før hun skal gøre det rent, forretter bagermester Schmidt i »Mens dejen hæver« sin nødtørft til stor gene for pigen, der må gå om bag huset med sit ærinde (jfr. p. 120). Magten over lokummet er mandens privilegium her i begyndelsen af suiten. Og hvor Jensens magtudøvelse udløste Bothildes (berettigede) vrede, er det her Schmidt selv der er et arrigt svin. Han er nok samlingens mest gennemførte skurk, tyranniserer sine ansatte, gennembanker sin datter og foragter stort set alle andre i landsbyen. At Seeberg fremviser ham ved novellens begyndelse med åben lokumsdør og i bogstavelig forstand bukserne nede, understreger lokummet som et betydningsfuldt sted i landsbyuniverset. Ved at den mere amorfe forrettelse af nødtøften i naturen er blevet centraliseret og privatiseret i lokummet, er dette også blevet stedet for magtkampe og for dominans. I den tidligt moderne verden, Sønderjylland 1927 er det stedet for undertrykkelsen af de naturlige behov. Det hænger som antydet også sammen med undertrykkelsen af andre behov, først og fremmest seksuelle. Det vender jeg tilbage til.

Man skulle i dette univers tro, at jernbanen måtte være et middel til undslippelse og befrielse fra misèren. Jernbanen er ustandseligt til stede i novellerne, man går langs med den, krydser den, ser og hører den. Men ingen af personerne i historierne undslipper til en større verden via den. Den fører på en mærkelig måde ingen steder hen. Den længste rejse af alle foretager skræddermester Haunstrup, der i novellen »Ansats til selvforsvar« besøger sin kone på sygehuset i nabobyen og vender tilbage med sidste tog. En rejse, der ikke alene konfronterer ham med konens forfaldne legeme, men også med andre former for skidt og møg (herunder det slim han hele tiden med væmmelse hoster op), og den kniv han sidder og leger med til sidst er til forsvar mod den ækle verden, han ikke kan undslippe. Heller ikke med tog. Toget kommer med ting fra omverdenen, bl.a. de fisk der i novellen »Tilintetgørelsen« ender med at tage livet af fiskehandler Bertelsen - men sporet kan ikke bruges til flugt. Det fører intet sted hen. 
Nej, skal der rejses, bliver det inden for landsbyen og skal der flygtes bliver det tilbage til forældrene. I den forstand er det rimeligt, at stationsbygningen med tilhørende lokum både begynder og slutter suiten. Den er ikke udgangspunktet for rejsen, men det man kommer hjem til. Hic Rhodus, hic salta.

To af de midterste noveller i suiten handler direkte om at rejse og om at komme 'hjem', men på en mere tvetydig måde end sneglens, der endeligt lukker samlingen. »Odyssé for en niårig« er renset for al mytisk patos og mindelser om den snarrådige helt fra Ithaka, her bevæger en dreng sig gennem byen, sideordnet og neutralt registrerende hvad der sker omkring ham, indtil han kommer hjem til et tomt hus, spiser lidt og går ud for at finde nogen at lege med. Så neddæmpet og cool som hos genrens store mester, James Joyce i hans Dubliners. Alligevel er det en truet neutralitet, drengen opretholder i forholdet til verden. Der er noget galt mellem forældrene, bortset fra at de ikke er der. Moderens chef manufakturhandleren går og tager på hende, men hun kan ikke få andet job, og familien behøver pengene. Og det seksuelle er i det hele taget noget ulækkert noget, som finder sted på hundemaner, også selv om det er mennesker, der gør det. Og drengen er lige så utilpas ved at se på kopulerende hunde, som han er ved at se på fotografens udstillingsvindue, "han syntes bedre om sig selv indefra" som han gysende registrerer ved tanken om selv at være blevet fotograferet. Det seksuelle er forbundet med eksponering og udstilling og har for drengen noget dyrisk ved sig. Om hanhunden ved man heller ikke rigtigt, hvad den kan finde på: »(den) stod stille og så sig om og så over den store plads og over mod stationens toiletbygning. Måske gik den i lokummerne« (p. 137). Det er som om de lokummer ligger og udgør et farligt punkt i drengens byunivers. Han kommer fordi dem og hjem, som Odysseus kom forbi Charybdis, men uden triumf. Det er som om fortællingens neutralitet er tilkæmpet over et farefuldt farvand.

Det gælder også i den næste historie »Flugt tilbage«, hvor pigen Dagmar også kommer hjem til et tomt hus: ikke bogstaveligt, for både mor, far og storebror er der, men psykisk er hun lige så forladt som drengen Odysseus. Da hun om aftenen ligger i sengen ved siden af broderen, har hun kun sin indre tanke at klamre sig til: »Hun kunne tænke hvad hun ville« (p. 154). I alt andet er hun underlagt de andres vilje.

Dagmar er som drengen bange for kombinationen af afføring og seksualitet: »Hun havde altid været bange for lort«, står der med en formulering, som man næsten ikke kan tro er Dagmars egen. På den anden side: hendes tanker har hun jo for sig selv. Måske fordi hun frygter det, er hun hele tiden omgivet af det eller andre påtrængende kødelige fænomener: en lastbil med kadavre til destruktionsanstalten, renovationsmanden der tømmer lokummer, 
lærerkonens fede arme og ulækre bryster, hendes ækle gebis, folk der brækker sig til en fest etc., etc. I sine sparsomme seksuelle fantasier forestiller hun sig da også akten nærmest som en slagteproces: »Hun var syg af at tænke på Svend. Hun gispede efter vejret. Hun forestillede sig, at han kom med en stor saks og klippede tøjet af hende nedefra, så det faldt af hende, og hun var helt bar« (p. 151). Hendes drøm gentager det, hun frygter mest af alt: råt kød, et kadaver, lort. Også på anden måde fungerer hendes krop som viljesløst kød: »Midt i strygningen måtte hun ned i rosinerne og op i kagekassen. Hun kunne modstå et stykke tid, men ikke hele eftermiddagen« (p. 152). Ikke så sært at hun ikke kan spise noget af moderens ulækre stegte flæsk, da hun kommer hjem. Hun er omgivet af og er i det triste kød, og kan ikke undslippe. Her er ingen 'hjemkomst' mulig.

At seksuel frustration udløser en invasion af påtrængende indtryk omkring smuds og afføring vises også i »Ingen kunder i salonen endnu« om frisørmester Egon Jensen, der er blevet forladt af sin kone og nu henslæber et liv, hvor han har svært ved at holde farlige og destruktive tanker på afstand. Fosterfordrivelse er jo egentlig hans fag, ender han med at tænke, men »så glemte han det igen", som fortælleren nøgternt konstaterer (p. 119). Yderst raffineret bevæger den Seebergske fortællerstemme sig ud og ind af personerne, loyalt, men alligevel distanceret, umærkeligt. Alle de påtrængende og væmmelige ting, der omgiver Jensen i hans butik, kan man derfor ikke gøre hans frustrerede tankeverden ansvarlig for - og alligevel: alle de spekulationer over kondomer og deres anvendelse, al den oversvømmelse af salonen og det forhold, at folk står og pisser i hans trappeopgang og ikke benytter de nærliggende toiletter: alt dette er udtryk for, at en abjektal verden invaderer et menneske, der er berøvet det vigtigste: kærligheden. De menneskelige afføringsprocesser er diskret, men vedholdende til stede i den del af disse noveller om den sønderjyske stationsby, hvor magt, angst og seksuel frustration endnu råder.

Men så er der pludselig sket noget: kampen er ophørt og derved er afføring, smuds og lokummer forsvundet ud af teksterne. Vi opdager nu, at de kun er til stede, når der er konflikter på spil. »Hvad er der sket«, spørger arbejderformanden Harry Mortensen i »Ensomheden eksisterer ikke mere» en dag, han kommer hjem og finder sine forundrede drenge gumlende på et eller andet. Men uden spørgsmålstegn, nærmest konstaterende: et mirakel har indfundet sig i landsbyen, apotekerdefektricen Ulla Jacobsen har uddelt lakrids til børnene, uden nogen grund, bare fordi hun havde lyst. Godheden, den suveræne kærlighedshandling har fundet sted midt i stationsbyen, og noget har endegyldigt forandret sig.

Man har diskuteret kristendommens og de kristne symbolers betydning for Seeberg, sidst har Knud Bjarne Gjesing plæderet for, at Tidehvervs 
livssyn er centralt for forståelsen af Seebergs værk. ${ }^{15}$ Jeg skal ikke blande mig i striden, men kan ikke undgå at se Ulla Jakobsen som en slags kvindelig Kristus her i suiten af historier fra den sønderjydske stationsby, og vil minde om, hvordan den tidligere omtalte samling af byhistorier, Joyces Dubliners også figurerer fremvæksten af en kvindelig frelserfigur, kulminerende i Gretta i sluthistorien »The Dead«, der iværksætter en vending hos sin mand Gabriel, der i alt fald har konturerne af en frelse. ${ }^{16}$ På samme måde som Gretta kan opnå denne virkning ved at undvige det seksuelle, er Ulla Jakobsen så grim, at hendes erotiske muligheder næppe vil være store; og da hun i den sidste historie afløses af en anden frelsende kvindelig engel, Hulda, er det nu en husbestyrerinde, der udøver den gode gerning og derfor per definition en kvinde uden seksuel forbindelse til den mand, der har behov for frelse. Da det seksuelle forsvinder, indfinder godheden sig og med den forsvinder også alle besværligheder med skidt, afføring, forrådnelse og hvad der ellers har plaget personerne. Kampen om lokummet har fundet sin udgang med den triumferende (kvindelige) Kristus. Det er selvfølgelig helt urimeligt at forlange så meget af en apotekerdefektrice, og ironien ligger da også latent i novellens slutning, hvor fortælleren trækker landsbyens håb til Ulla ind i den kortspilsmetafor, der er blevet brugt tidligere: »Træk føjer sig til træk. De samler på hende.... Hun er i forhånd. I adskillige år er der mange, der venter endnu et overraskende udspil fra Ulla Jacobsen« (p. 174). Men det ændrer ikke ved, at en engel er gået igennem byen og har tændt håbet i de bekymrede hjerter.

Godheden i slutningen af historierne om den sønderjyske stationsby er dog ikke kun kvindelig. Skovhuggeren Bertram i »Angivelse af et tidspunkt» repræsenterer den også og udøver den i det sarte samvær med barnebarnet, der bringer ham kaffe i skoven. Og samtidigt får vi i denne novelle en forklaring på den dato, d. 27. november, der har været underskriften på alle historierne: det er tæt på advent, nu skal juletræet komme, der bebuder Jesu fødsel. Diskret, men tydeligt sættes der an til et symbol, der baner sig vej i samspil med de to noveller, der omgiver den. Gerhards kone, Astrid, vasker ikke hans fødder til sidst - det ville være alt for tydeligt, men hun kommer med »lidt varmt vand fra kedlen« til ham »og lader døren stå, så lyset kan falde ud til ham« (p. 180). Et bastant, sakralt symbol ville have ødelagt sin virkning, så diskret som her lyser det i mørket.

Seeberg ville dog ikke være Seeberg, hvis ikke frelsetemaet modereredes en smule til allersidst, og såmænd om ikke urenhed og svinskhed også her

15. Se f.eks. hans efterord til udgaven af Seebergs Tre tidlige fortcellinger, Odense 2000.

16. Se min Dødens vark. Fem kapitler om døden i moderne litteratur, litteraturteori og psykoanalyse, Århus 2000, p. 273 ff. 
spiller en rolle. I novellen, der har givet hele samlingen navn, befinder det fortællende jeg sig et mellem-sted på vej til Paradis, hvor han venter på at hans elskede skal ankomme. Måske om fjorten dage, måske slet ikke, under alle omstændigheder vil hun ankomme med tog, og fortælleren vil vente på hende uden for stationen, på stationspladsen. Vi er i Limbo og dog stadigvæk i en sønderjysk landsby, »tiden her er lang, men ikke tung« (p. 219).

Og det er den ikke, fordi jeg'et har selskab af Breshnev (der i 1981 lige var død), der lige som han ikke er specielt interesseret $\mathrm{i}$ at skulle videre til det egentlige paradis. Han vil hellere gå rundt her i ubestemtheden og »fortælle uartige historier især barnlige historier om urenlighed og svinskhed, og han har næsten fortalt alle, han kan huske. Derpå må vi fortælle dem igen eller digte nye for at gøre os vanskeligere endnu« (p. 220). Fortæller de ikke disse svinske anekdoter, ender de nemlig med at blive forklarede og må stige til vejrs. Det vil de to fyre undgå for enhver pris. Hvis fortællerens elskede ankommer og ser på, vil hun som Dantes Beatrice trække digteren op i lyset, holder han sig til Breshnevs sjoferter og fantasterier får han måske lov til at forblive i den behagelige og helt igennem menneskelige mellemzone: »Menneskeverden, omskiftelighed, uforbederlighed, den lod vil jeg, at jeg atter kunne dele« (p. 221). Til denne verden hører smudset og affaldet som en naturlig del.

Følger vi altså toposen 'affald, smuds og afføring' igennem Om fjorten dage ser vi, at den har to betydninger: dels er dette smuds noget der stadig klæber angst og væmmelse ved, og som må overvindes, hvis godheden skal sejre i menneskelivet. På den anden side udgør disse sager en naturlig del af samme menneskeliv, som vi bliver nødt til at være åbne og fordomsfrie over for, hvis ikke dette liv skal visne i forklarelse og overjordiskhed. »Bleibt der Erde treu«, som Zarathustra prædiker for sine disciple, i samme åndedrag som han deklamerer, at mennesket er noget, der bør overvindes. Måske var det Seeberg mest lærte af Nietzsche modet til at være selvmodsigende, at hjertets renhed er at ville en to-tre ting på én gang. Den form for urenhed har måske også noget med afføringstemaet at gøre, men det er en anden - og længere - historie. 